\title{
Sixth Method as a Simplified Measurement for SMEs?
}

\author{
Veronika Solilová - Danuše Nerudová
}

\begin{abstract}
:
In December 2014, OECD issued a Discussion Draft on Transfer Pricing aspects of cross-border commodity transactions through BEPS action 10, where the adoption of the sixth method in the form of the quoted commodity price and its adjustments were primarily driven as a starting point for transfer pricing purpose. In this paper the analysis of the proposed sixth method and the experience with the sixth method in Argentina were used for the consideration whether this method can be used as simplified measurement for SMEs. SMEs are facing tax obstacles mainly in the area of the international taxation which impede in cross border transactions and internationalization of SMEs. One of tax obstacles represent transfer pricing. Its costs can be disproportionately large for SMEs in comparison to LSEs. Moreover, SMEs are not able to bear the high administrative burden to comply with the transfer pricing rules as they do not posses the sufficient human and economic capital. Based on the results of the research, we can concluded, that there are a lot of questions related to the proposed sixth method, notwitstanding, it has a potential to be a new method for SMEs for they need to face lower tax administrative burden in the area of transfer pricing issues.
\end{abstract}

Keywords: Sixth method; SMEs; Transfer pricing; Simplified measurements; BEPS.

JEL classification: $\mathrm{H} 25, \mathrm{H} 26$.

\section{Introduction}

The Committee on Fiscal Affairs, which is the main tax policy body of the OECD, has began to coordinate transfer pricing rules since 1979 by publishing a number of reports relating to the transfer pricing issues. As the most important can be considered Transfer Pricing Guidelines for Multinational Enterprises and Tax Authorities (hereinafter OECD TP Guidelines) which were published as a summary guideline in 1995, and are constantly revised.

The cornerstone of the transfer pricing rules represents the application of the arm's length principle, under which the effect of special conditions on the levels of profits and profit base erosion should be eliminated. The arm's length principle is

\footnotetext{
Veronika Solilová; Faculty of Business and Economics, Department of Accounting and Taxation, Mendel University, Zemedelska 1, 61300 Brno, Czech Republic; <ritve@email.cz>.

Danuše Nerudová; Faculty of Business and Economics, Department of Accounting and Taxation, Mendel University, Zemedelska 1, 61300 Brno, Czech Republic; <d.nerudova@seznam.cz>.

The article is processed as an output of a research project Name of the project registered by the Grant Agency under the registration number 15-24867S „Small and medium size enterprises in global competition: Development of specific transfer pricing methodology reflecting their specificities".
} 
incorporated in the Art. 9 of the OECD Model Tax Convention on Income and on Capital (OECD Model Tax Convention), and in the UN Model Tax Convention between Developed and Developing Nations. However, from the beginning of existence the OECD TP Guidelines as a guideline for the practical application of the arm's length principle, significant difficulties with identifying suitable comparables had been identified. This often requires the usage of sophisticated microeconomic techniques, which nevertheless can produce only a range of possible arm's length prices that are often significantly broader than good tax policy could ever suggest. Moreover, in this respect, even small differences can have a significant effect on the attributable profit.

Further, applying the arm's length principle represents a resource-intensive process, because it may impose a heavy administrative burden on taxpayers and tax administrations. It may require collection and analysis of data that may be difficult or costly to obtain and/or evaluate. Moreover, such compliance costs may be disproportionate to the size of the taxpayer, its functions performed, and the transfer pricing risks assumed in its controlled transactions, as OECD TP Guidelines make no direct distinction between types or sizes of multinational entities (hereinafter as MNEs). In theory, all enterprises, regardless of their size, are subjected to the same principles and recommendations. Hence, re-evaluation of transfer pricing rules should be considered to obtain greater simplicity in transfer pricing administration and improving the efficiency and effectiveness of transfer pricing enforcement.

Due to the fact that the practice shows a lack of adequate comparables especially in case of small and underdeveloped economies, some of those countries have introduced methods which are easier to administer. As an example can serve Brazil's with its fixed margins, Argentina with its sixth method for commodities and other Latin American countries. Therefore, OECD subjected those alternative methods to analysis and on December, 2014 issued a Discussion Draft on Transfer Pricing aspects of cross-border commodity transactions through Base erosion and profit shifting (BEPS) ${ }^{1}$ action 10, where the adoption of the sixth method in the form of the quoted commodity price and its adjustments were primarily driven as a starting point for transfer pricing purpose.

The aim of the paper is to evaluate and consider whether sixth method can be used as simplified measurement for SMEs, based on the analysis of the proposed sixth method by OECD and experience with the sixth method in Argentina.

\footnotetext{
BEPS refers to tax planning strategies that exploit gaps and mismatches in tax rules to artificially shift profits to low or no-tax locations where there is little or no economic activity, resulting in little or no overall corporate tax being paid. This undermines the fairness and integrity of tax systems.
} 


\section{Theoretical Background}

European Commission (2010) states, based on the survey created by Directorate General of Enterprise and Industry, that more than $44 \%$ of SMEs (in EU average) are active in any forms of international activities ${ }^{2}$ within the EU. However, only $2 \%$ (for micro), $6 \%$ (for small) and 16\% (for medium) of SMEs are investing abroad, and only $5 \%$ of SMEs have foreign subsidiaries. Due to the fact that SMEs are considered to be crucial for the European economy, their internationalization in the form of cross-borde activities seems to be essential.

SMEs differ very significantly from large enterprises (hereinafter as LSEs) in many aspects, for example in size, activities, needs, resources, labour productivity, in the qualification and skill levels of the employees and capital intensity. From the international taxation perspective, SMEs are facing specific problems and face higher compliance costs of taxation which are generated mainly in connection with non-existence of unified system of SMEs taxation (i.e. there are 28 different tax system in EU), the number of taxes that must be complied with, the frequency of changes to the tax laws, the complexity of the tax system, the existence of different tax administrations, the difficulty associated with interpreting unclear tax laws, multiple deadlines for tax payments throughout the year, costs of external tax service providers as well as internal staff or owner time spent complying, and tax registration procedures as states European Commission (2007). Tax compliance costs involve a large fixed component and impose a relatively higher burden on SMEs than on LSEs which can benefit from economies of scale. Further, they face transfer prices issues and problems with cross-border loss compensations. Althouth those tax obstacles are identical also for LSEs, its impact on SMEs is greater, for they do not posses enough human and financial capital to overcome those obstacles.

As defines Van Herksen (2009), transfer pricing represents the specialization within the field of international and corporate tax law aiming to determine the arm's length transfer price for the products and services sold or rendered between associated companies 3 . The term "arm's length" means "fair value" or "market value" or a value that is not influenced upwards or downwards by the relation between the companies. The ability to set internal prices ${ }^{4}$ that differ from market prices represents a good indicator of such relationships.

In respect of the transfer pricing issues and the determination of arm's length prices, associated costs can be disproportionately large for SMEs in comparison to

2 i.e. exporting, importing, investing abroad, cooperating internationally, or having international subcontractor relationships.

3 Associated companies/ related persons should be defined as including two or more companies/persons that are owned or controlled, directly or indirectly, by the same interests.

4 These internal prices are called transfer prices. 
LSEs for both, the taxpayer and the tax administration. OECD TP Guidelines (2010) provide that application of the transfer pricing rules may be more complex for SMEs in several places and therefore too burdensome. Due to this fact OECD launched the project on the administrative aspects of transfer pricing in 2010 with a partial result in the form of the revision of the Section E on Safe Harbours in Chapter IV of the OECD TP Guidelines, which brings important change in the view on the safe harbours ${ }^{5}$, as possible simplified transfer pricing measurement. The same approach to safe harbours was also explicitly endorsed in the EU Joint Transfer Pricing Forum (hereinafter EU JTPF) report "Transfer Pricing and Small and Medium-Sized Enterprises" and in other EU JTPF report "Guidelines on Low Value Adding Intra-Group Services", where low value adding services are valuated by mark-up in the range of 3-10\%, often around 5\%.

Currently, $75 \%$ of the simplified transfer pricing measurements are introduced for SMEs covering usually areas of the low-value added intra group transactions, loans, transfer pricing documentation and small transactions. Further, half of EU Member States apply simplified measurements for SMEs in case of TP documentation: Ireland, Hungary and the United Kingdom exclude SMEs from transfer pricing rules fully, as SMEs are not able to bear the high administrative burden to comply with the transfer pricing rules. However, as they further add, there are not any simplified measurements in the form of specific method for SMEs.

Further, as practice shows, transfer pricing as an instrument of tax planning, is usually used by LSEs and not by SMEs. In case of LSEs transfer pricing strategies enable the distribution of the tax risks and tax planning. This fact increases the costs associated with transfer pricing issues. Moreover, transfer pricing is subjected to the strict tax regulations and control as any tax administration wants to secure the tax base with minimal level of tax evasion and fraud. When the taxable profit is not recorded in the source state due to a special relationship between associated entities (i.e. if transfer prices do not fulfill the arm's length principle) and there is a risk of the tax evasion with the elements of harmful tax competition, then the tax authorities may adjust the tax base of the entity. Furthermore, as Buus, Brada (2008) mention the frequency and size of possible tax evasion is greater for commodities, which are not standardized and traded on public markets. Therefore, the references on the quoted price of the tradable commodities on exchanges (as the sixth method), where standardize the quantity and minimum quality of the products are traded, seems to be reasonable. Moreover, the commodity sector provides the major source of economic activity

\footnotetext{
A safe harbour in a transfer pricing regime is a provision that applies to a defined category of taxpayers or transactions and that relieves eligible taxpayers from certain obligations otherwise imposed by a country's general transfer pricing rules. A safe harbour substitutes simpler obligations for those under the general transfer pricing regime.
} 
and government revenues mainly for developing countries, hence a lot of them introduced similar or sixth method in their legislation. In addition, from the global perspective, addressing deliberate tax evasion and fraud is also the aim of the BEPS project which ensures that a government receives tools to ensure that profits are taxed where economic activities generating the profits are performed and where value is created, while at the same time give business greater certainty by reducing disputes over the application of international tax rules, and standardizing requirements. BEPS project focuses on 15 specific key areas, where one of them is transfer pricing issue.

In respect of the second tax obstacle - compliance costs of taxation - Nerudová, Bohušová, Svoboda, Široký (2009) and Cressy (2000) mention that compliance costs of taxation have regressive character with respect to the size of the enterprise which is significantly higher in case of SMEs with foreign branch or subsidiary in comparison with SMEs which are not internationalized. Chittenden, Michaleas, Poutziouris (2000) further state that compliance costs are hundred times higher for SMEs than for LSEs. The solution for decreasing those costs as states Sandford (1995) could be an international competitiveness of entities.

Another tax obstacle to cross-border activities of the SMEs represents the problem with cross-border loss compensations as mentions Nerudová (2005). Currently, there are 7 EU Member States not providing the possibility of cross-border loss compensation - the Czech Republic, Belgium, Greece, Lithuania, Hungary, the Slovak Republic and Estonia. However, the LSEs contrary to SMEs can influence offsetting of losses by the properly chosen transfer pricing strategy. Nerudová, Bohušová, Svoboda, Siroký (2009) mention that possibility of cross-border loss offsetting would increase activities of SMEs in abroad.

\section{Methodology}

To reach the aim of the paper, firstly the proposed sixth method and the experience with the sixth method in Argentina were researched. Secondly, the research focused on the analysis of the potential tradable commodities and the mapping of industry where SMEs are operating and which is related with trading of commodities on exchanges. As a data source is used mainly the OECD Discussion Draft on Transfer Pricing aspects of cross-border commodity transactions through BEPS action 10, Income tax law No. 25.784 of Argentina and NACE classification of industry.

Within the paper, the analysis, desciption and synthesis as scientific methods were used for the introduction of the proposed new sixth method, the experience with the sixth method in Argentina, and for the potential tradable commodities together with the mapping of industry where those commodities are produced and/or transfered. Furthermore, the method of comparative analysis was used to compare the proposed sixth method with the method applied in Argentina. In addition, the 
others methods, namely induction and deduction were applied in the process of the suggestion of recommendations on the use of the sixth method as a simplified measurement for SMEs.

In the end, the Amadeus database ${ }^{6}$ was used to identify examples of SMEs operating in economy sectors where the commodities are produced and/or transferred. Only those SMEs can benefit from using the new proposed sixth method to decrease its tax administrative burden in the area of transfer pricing issues.

\section{Results}

\subsection{Sixth method based on the proposal of the OECD}

The OECD proposes inserting the following guidelines into the OECD Transfer Pricing Guidelines. The comparable uncontrolled price method (hereinafter CUP method) can be an appropriate transfer pricing method for establishing the arm's length price for the transfer of commodities ${ }^{7}$ for which a quoted or public price is available ("quoted price"), subject to the conditions of the controlled transaction and the conditions of the quoted prices being comparable. It means, that the quoted price needs to be similar, in terms of the physical features and quality of the commodity. In addition, the contractual terms such as volumes traded and the timing and terms of delivery of the controlled transaction should also be considered. Otherwise, if there are differences between the conditions of the controlled transaction and the conditions determining the quoted price for the commodity that materially affect the price of the commodity, reasonably accurate adjustments should be made to ensure that the economically relevant characteristics of the transactions are sufficiently similar. Such differences can be related, for instance, to the different specificities of the commodity (e.g. premiums for quality or availability of the commodity), different processing functions performed or required, or additional costs incurred for transportation, insurance or foreign currency terms.

Under the CUP method, the arm's length price for commodity transactions may be determined by the quoted price of the commodity in the relevant period obtained in an international or domestic commodity exchange market (e.g. London Metal Exchange, Chicago Board of Trade, Tokyo Grain Exchange). Further, quoted price also includes prices obtained from recognized and transparent price reporting or statistical agencies (e.g. Platts, Argus or Bloomberg) or from governmental price-

6 Amadeus database contains comprehensive financial and basic textual information on European companies across Europe (44 European countries). Amadeus database used for the research covers very large, large, medium and small companies, altogether 21,815,160 companies, version 11.01, release 244, January 2015.

7 Commodities mean physical products for which a quoted price is used by independent parties in the industry to set prices in uncontrolled transactions. 
setting agencies, where such indexes are used by unrelated parties to determine prices in transactions between them. Quoted commodity prices generally reflect the agreement between independent buyers and sellers in the market on the price for a specific type and amount of commodity, traded under specific conditions at a certain point in time. A pricing date is a particularly relevant factor for commodity transactions, which refers to the specific date or time period (e.g. a specified range of dates in which an average price is determined) selected by the parties to determine the price. If there is not evidence in the actual pricing date, tax administrations may deem the pricing date for the commodity transaction to be the date of shipment as evidenced by the bill of lading or equivalent document depending on the means of transport. In additon, a relevant factor in determining the appropriateness of using the quoted price for a specific commodity is the extent to which the quoted price is widely and routinely used in the ordinary course of business in the industry.

There is a simple example of how a commodity transaction would be tested using a quoted price, and which common adjustments can be used:

On July 26th, 2015, a company located in Frankfurt purchases 10 metric tons ( $m$ ts) of cocoa beans from a related party in Brazil for \$3,297/M ton (the contract has a total value of \$32,970). Cocoa beans sold in the intercompany transaction are of a similar type, quality and quantity as those traded on the Frankfurt Stock Exchange ("FSE"). The FSE's low and high spot price of a 1 metric of cocoa was from $\$ 3,274$ to $\$ 3,297$ on the same day. Also, assume both prices are inclusive of the necessary fees to transport cocoa from Brazil to Frankfurt (e.g. transportation, insurance, duties/taxes) and no other material differences are found between the controlled and uncontrolled transactions. Based on these facts, the controlled transaction is comparable to the uncontrolled transactions reflected by the quoted prices, and the controlled price is within the high and low prices quoted on the commodity exchange; therefore, the intercompany transaction is considered arm's length.

\section{i. Quantity Adjustment:}

On January 26th, 2015, a company located in Frankfurt purchases 11,020lbs of cocoa beans from a related party in Brazil for \$16,485.00. Cocoa beans sold in the intercompany transaction are of a similar type and quality (but not quantity) as those traded on the FSE. The FSE's low and high spot price of a 1 metric of cocoa was from $\$ 3,274$ to $\$ 3,297$ on the same day. The FSE only trades in $1 \mathrm{mts}$ so the contract price of $\$ 16,485.00$ must be converted to a market-weight price (i.e. $\$ 16,485.00 / 11,020 \mathrm{lbs}=\$ 1.4959 / \mathrm{lbs}$ and $1 \mathrm{mt}=2,204 \mathrm{lbs}$, so $\$ 1.4959 *$ $2,204 \mathrm{lbs}=\$ 3,297 / \mathrm{mts}$.). Again, assume both market-weight prices are inclusive of the necessary fees to transport the cocoa beans from Brazil to Frankfurt (e.g., transportation, insurance, duties/taxes) and no other materiál differences are 
Solilová, V. - Nerudová, D.: Sixth Method as a Simplified Measurement for SMEs?

found between the controlled and uncontrolled transactions. Based on these facts, the controlled transaction is comparable to the uncontrolled transactions reflected by the quoted prices, and the controlled price is within the high and low prices quoted on the commodity exchange; therefore the intercompany transaction is considered arm's length.

ii. Basis Adjustment:

On January 26th, 2015, a company located in London purchases 10 metric tons (mts) of cocoa beans from a related party in Brazil for \$3,135/M ton. Cocoa beans sold in the intercompany transaction are of a similar type, quality and quantity as those traded on the FSE. The FSE's low and high spot price of a 1 metric of cocoa was from $\$ 3,274$ to $\$ 3,297$ on the same day. Also, assume the quoted prices on the FSE are inclusive of the necessary fees to transport cocoa from Brazil to Frankfurt (e.g., transportation, insurance, duties/taxes) and no other material differences are found between the controlled and uncontrolled transactions. To test this transaction an adjustment must be made related to the freight/transportation reflected in each price related to the different delivery destinations (i.e., Frankfurt vs. London). As stated above, the spot price quoted on the FSE includes "the necessary fees to transport cocoa from Brazil to Frankfurt; however, the controlled price reflects transportation cost to London. As such, an adjustment must be made to the FSE quoted prices to reflect delivery to London instead of Frankfurt. The adjustment in freight price of a $1 \mathrm{mts}$ of cocoa from Brazil for delivery to London is negative $\$ 150$ (i.e. it is $\$ 150$ cheaper to deliver a $1 \mathrm{mts}$ of cocoa from Brazil to London, than it is to deliver the same amount of cocoa to Frankfurt). Therefore, the low and high spot price of a $1 \mathrm{mts}$ of Brazilian cocoa purchased on the FSE, but with delivery to London is from $\$ 3,124$ to $\$ 3,147$. Based on these facts, the controlled transaction is comparable to the uncontrolled transactions reflected by the quoted prices, and the controlled price is within the adjusted high and low prices quoted on the commodity exchange; therefore the intercompany transaction is considered arm 's length.

iii. Product-Type Adjustment:

On January 26th, 2015, a company located in Frankfurt (Company X) purchases 1 metric ton of standard cocoa butter from a related party in Congo (Company $Y$ ) for \$4,930. The cocoa butter is purchased in blocks and is to be made from African cocoa beans, which are of similar type, quality and quantity to cocoa beans traded on the Intercontinental Exchange (ICE). The ICE trades only cocoa beans (i.e., it does not trade cocoa butter) in metric ton lots; therefore, when Company $Y$ sells cocoa butter to related or unrelated parties, it typically adjusts the price of the cocoa beans quoted on the ICE using multipliers published by independent sources. The ICE's low and high spot price for a metric ton of African cocoa beans was from \$3,277.00 to \$3,303.00 for the same day. Also, 
assume both prices are inclusive of the necessary fees to transport the beans from Africa to Frankfurt (e.g., transportation, insurance, duties/taxes) and no other material differences are found between the controlled and uncontrolled transactions. To test this transaction, a product-type adjustment must be made in order to account for the product differences between the cocoa beans traded on the ICE and the cocoa butter purchased in the intercompany transaction. Company $Y$ uses information from an independent source to determine that a multiplier of 1.5 should be used to adjust the ICE quoted price for one metric ton of African cocoa beans to account for the lower yield and additional fee associated with making cocoa butter blocks. Therefore, the low and high spot price for one metric ton of standard African cocoa butter blocks purchased on the ICE is from $\$ 4,915.50$ to $\$ 4,954.50$. Based on these facts, the controlled transaction is comparable to the uncontrolled transactions reflected by the quoted prices, and the controlled price is within the adjusted high and low prices quoted on the commodity exchange; therefore, the intercompany transaction is considered arm's length.

\subsection{Experience in the application of the "sixth method" in Argentina}

Argentina is a major food producer at a worldwide level. In 2013 it was the first world exporter of soybean oil, the second world exporter of peanut oil, the third world exporter of corn and the eight world exporter of wheat. Further, the grain and oilseed industry contributed jointly with $37 \%$ (30.4 billion dollars) to the total country exports. Therefore, there is no doubt why tax authorities try to prevent from speculating with pricing by exporters and try to find a tool to avoid base erosion at source-country level. In this perspective, the "sixth method" can be considered as a suitable tool.

Generally, Argentine Income Tax Law (hereinafter ITL) provides statement of the arm's length principle for determining transfer pricing prices between affiliated companies. Further, this provision adds, in line with the OECD Transfer Pricing Guindeines, that in order to determine such prices "the most appropriate method will be used according to the type of transaction made." For such purposes, the ITL mentiones following methods: the Comparable Uncontrolled Price, Resale Price, Cost-Plus, Profit-Split and Transactional Net Margin Methods. Furthermore, ITL in Article 21/2 states the definition of comparable transactions as a transaction there are no differences affecting the price, profit margin or consideration amount or when such differences can be eliminated through adjustments that allow for a substantial comparability. Moreover, Article 21/5 ITL allows the utilization of the interquartile range and the median, as proper statistical measures. In the end, there are also implemented decrees, for example Decree 916/04 of the Argentine Executive Branch. 
However, on October 2003, Argentina as the first country adopted the sixth method which substantially modified transfer pricing framework in ITL by Law No. 25.784, in Article 15. Amended Article 15 of ITL states, that exports made to affiliated parties, of grains, oilseeds, other landrelated products, hydrocarbons and their by-products, and in general, goods with known prices in transparent markets (i.e. listed price) handled by an international intermediary who is not the actual receiver of the goods, shall be valued at the higher of the following two prices (i) the "listed price of the goods at the date in which the merchandise is shipped" or (ii) "the price agreed with the international intermediary".

Thus, under the sixth method the commodity transaction has to be priced, for transfer pricing purposes, at the quoted price in the transparent market at the date goods are loaded (whatever the means of transportation), provided such quoted price is higher than the price agreed upon by the parties to the transaction (i.e. international intermediary). However, if the price agreed with the international intermediary were to be higher than the market price in force at the date of loading of the goods, the first of them will be considered for tax purposes.

Furhter, amended Article 15/8a,b,c of ITL states, that it is required to apply the sixth method if the other party to the transaction is a trader (international intemediary) that does not meet the conditions established by that article; otherwise, if the trader meets the conditions or if it is the actual recipient of the goods, the CUP method shall apply. Concretely, based on the conditions, sixth method shall not apply to the extent the international trader satisfies a substance test:

- it has actual presence in its territory of residence, with commercial premises for the administration of the business, and compliance with the legal requirements of organization and registration and reporting of financial statements. The assets, risks and functions undertaken by the international trader should be consistent with the volumes of the transactions conducted;

- the international trader's main activity does not consist in obtaining passive income, nor in the intermediation of commodities from and to Argentina or with other members of the economically related group;

- and the trader's international trade transactions with members of the same economic group should not exceed thirty percent (30\%) of the annual aggregate transactions concluded by the international trader.

It means, when an Argentine exporter of commodities sells to a related party located abroad through an "unsubstantiated" intermediary (i.e. the one who does not meet the substance test), then the sixth method did apply. However, an "unsubstantiated" intermediary is considered not to be arm's length or under the normal market conditions referred to in the Article 14/3 of the ITL." 
Moreover, the sixth method does not take into account the conditions agreed upon between the parties and the business circumstances, does not admit internal comparables and does not require that a range of comparable prices be developed.

In addition, Argentine legislation requires exporters to inform commodity crossborder transactions for trade regulation purposes to a special unit of the Ministry of Agriculture (i.e. the "UCESCI"). Further, in respect of transfer pricing issues, tax payer has to fill annual transfer pricing reports as well as six-month summarized reports.

Argentine sixth method has been widely construed by tax authorities as a major revenue tool, and not as an exceptional, last-resource method for proper application of the arm's length principle to determine prices in related-party transactions. Moreover, tax authorities often incur in straightforward application of the sixth method, systematically challenging the substance of any international trader, thus converting this exceptional methodology into a general rule.

In the end, other Latin American countries, such as Uruguay, Brazil and Paraguay, have also adopted specific transfer pricing rules for controlled commodity transactions but more flexible than the Argentine ones. They state the application of quoted prices in controlled commodity transactions, but on the date the prices are set between the parties, provided the taxpayer has reliable evidence of the pricing date actually agreed by the associated enterprises. The tax treatment is the same regardless of whether the related purchasing company is a trader or an actual recipient of the goods, provided the transaction is genuine.

\subsection{Analysis of SMEs in EU and potential tradable comodities}

Trading of commodities can be emloyed through future or forward contracts, where the buyer and seller agree to a price for a commodity, which is to be delivered at a mutually agreed date and quantity, or spot trading, where the delivery takes place immediately or in minimum time. Trading is carried out on exchanges that standardize the quantity and minimum quality of the products traded, for example on Chicago Board of Trade, Chicago Mercantile Exchange, Commodity Futures Trading Commission, Euronext, London International Financial Futures and Options Exchange, NASDAQ OMX Commodities, New York Board of Trade, Intercontinental Exchange and etc. Tradable commodities are usually categorized into four basic groups: agriculture, livestock, metals and energy. The table 1 in Annex presents examples of potential tradable commodities where the sixth method could be applied. As can be seen in the table, there are many agricultural and industrial commodities now being traded in the commodities market.

In 2014, across the EU28, there were 21.6 million SMEs in the nonfinancial business sector. However, only a small number of them is internationalized and has foreign subsidiary in other EU Member States. Based on the Amadeus 
database, we selected SMEs operating in EU28 having foreign subsidiary related to the industry sectors, where are produced or traded commodities mentioned above. Concretely, the total amount of 5,653 (see table below) entities were received (i.e. $0.026 \%$ of SMEs), where sectors of energy (mainly Electric power generation, transmission and distribution) and agriculture (mainly Growing of cereals (except rice), leguminous crops and oil seeds, and Animal production) cover the largest parts. Thus, only SMEs operating in NACE sector ${ }^{8} \mathrm{~A}$ (such as $01.11,01.12,01.14,01.16$ and 01.4), in sector B (such as 05, 06 and 07), in sector $\mathrm{D}$ (such as 35.1, 35.2 and 35.3) and in sector $\mathrm{G}$ (such as 46.11, 46.12, 46.21, 46.23, 46.71 and 46.72) would benefit from the application of the sixth method as a simplified measurement. As only SMEs operating in those sectors are producing and/or transfering commodities between each other and would be able to use the new sixth method which can decrease its tax administrative burden in the area of transfer pricing issues.

Tab. 1: Summary SMEs for application of the sixth method

\begin{tabular}{lccccc}
\hline NACE & $\begin{array}{c}\text { A- } \\
\text { industry }\end{array}$ & $\begin{array}{c}\text { B-Mining } \\
\text { And } \\
\text { Agriculture }\end{array}$ & $\begin{array}{c}\text { D-Electricity, } \\
\text { gas, steam and } \\
\text { air conditioning } \\
\text { supply }\end{array}$ & $\begin{array}{c}\text { G-Wholesale and } \\
\text { retail trade; repair } \\
\text { of motor vehicles } \\
\text { and motorcycles }\end{array}$ & Summary \\
\hline $\begin{array}{l}\text { No. } \\
\text { SMEs }\end{array}$ & 2,339 & 87 & 2,385 & 842 & $\mathbf{5 , 6 5 3}$ \\
\hline
\end{tabular}

Source: Amadeus database.

\section{Discussion}

The OECD proposal of the sixth method differs in comparison with the Argentine sixth method. The Argentine sixth method disregards proper income allocation to those countries where the hedging, distribution, marketing and commercial financing functions, among others, take place as it does not take into account the conditions agreed upon between the parties and the business circumstances. This situation can result in a source of unresolved international double taxation. Moreover, the Argentine sixth method also poses a conflict with arm's length principle, mainly due to disreaging the mechanics of price determination by unrelated parties; mandatoring application; arbitrary determination of the pricing date (e.i. relying on the higher price between the contract date vs. shipment date); and uncertainty about the final price as the market is volatile. Thus, the Argentine sixth method creates an unprecedented level of uncertainty for the industry. In addition, the Argentine sixth method originally intended as an exceptional antiavoidance rule soon became a prevalent methodology aimed at improving revenue collection.

8 For classification of each NACE codes see

http://ec.europa.eu/competition/mergers/cases/index/nace_all.html 
Contrary to the Argentine sixth method, the OECD proposal of the sixth method includes the consideration of the function performed, assets used and risks assumed. Thus, there are considered differences in product quality, traded volumes, market share, pricing date, costs, terms of transaction, market conditions, premiums or discounts and etc. The application of the sixth method is not mandatory as there is still the reference to internal comparables than the reference to the local quoted price. The OECD proposal of the sixth method should not disregard proper income allocation and should not pose a conflict with arm's length principle.

However, there are a lot of questions related to selection of the quoted price and the appropriate adjustments to it, which have effect on the determined arm's length price and consequently on the tax base of the trader in case of OECD proposal of the sixth method. For example, the quoted prices are different in the respect of the type of price (i.e. futures, forward or spot price) and whether use closing price, average price, lowest or higest price of the day or in selected period, further prices can differ in areas/exchanges (i.e. Malaysia area, Europe, America) and in terms of transaction (e. g. Incoterms as FOB9, CIF10, CFR11 and etc.) or whether prices cover duties related to exports or not. Further, in case of adjustments of the quated price, it is also important to understand the market and industry practice as the scope of tradable commodity is large and implies different business models. For example, if sales are conducted through a centralised entity, then the adjustments should reflect the functions performed and risks assumed by this entity, which will be included in the transfer price. In addition, the pricing of commodities can differ in relation to physical amount, different specifications, transport, processing cost etc. Another adjustment which should be taken into account is the delivery point. If delivery point is different from the geographic area, from which the relevant quoted price is used, then the relevant transportation costs should be added as adjustment of quoted price. Further, in case of a long-term agreement with a volume commitment and its renegotiation, bargaining power to find a realistic outcome at arm's length should be also considered. In the end, premium or demium/discount applied to commodity transactions according to their quality and origin should be considered as well.

We believe, that such adjustments could create major part of the arm's length price. Notwithstanding a lot of open questions, the quoted price as the sixth method, has a potential and can potentially be used as a reference to establish the price level at incerption or for the transaction performed with the parties who are

9 Free on board - transfer of the risk takes place before the transportation starts.

${ }^{10}$ Cost, insurance and freight - transfer of the risk takes place after delivering at destination. Therefore, the contract with CIF should be expensive than with FOB, as the risk is transferred later to the buyer.

11 Cost and freight. 
considered as the SMEs that need to have lower tax administrative burden in the area of transfer pricing issues.

\section{Conclusion}

The aim of the paper was, to evaluate and consider whether the sixth method can be used as simplified measurement in case of SMEs, based on the analysis of the proposed sixth method by OECD and experience with the sixth method in Argentina. Under the OECD proposal of the sixth method, the arm's length price for commodity transactions may be determined by the quoted price of the commodity in the relevant period obtained in an international or domestic commodity exchange market. Quoted commodity prices should reflect the agreement of the price for a specific type and amount of commodity, traded under specific conditions at a certain point in time. Further, conditions of the controlled transaction and the conditions of the quoted prices must be comparable, if there are differences that materially affect the price of the commodity, reasonably accurate adjustments should be made to ensure that the economically relevant characteristics of the transactions are sufficiently similar.

Contrary to the Argentine sixth method, the OECD proposal of the sixth method includes the consideration of the function performed, assets used and risks assumed, thus the new method should not disregard proper income allocation and should not pose a conflict with arm's length principle. However, there are a lot of questions related to the selection of the quoted price and the appropriate adjustments to it, which have effect on the determined arm's length price and consequently on the tax base of the trader.

Notwithstanding, quoted price as the sixth method, has a potential to become a reference of the price level at incerption or simplified measurements for SMEs that need to have lower tax administrative burden in the area of transfer pricing issues. SMEs who would benefit from the application of the sixth method operates mainly in NACE sector A (agriculture), in sector B (mining and quarrying), in sector D (energy) adn in sector $\mathrm{G}$ (wholesales trade). 


\section{References}

Amadeus Database, Bureau Van Dijk.

Buus, T.,Brada, J., 2008. O vlastnostech metod stanovení transferových cen.

Český finanční a účetní časopis 3, 39-55.

Chittenden, F., Michaelas, N., Poutziouris, P., 2000. Small Business Taxation: An Agenda for Growth, EDC: Manchester Business School.

Cressy, R., 2000. Tax, Assistance, Compliance and the Performance of the Smaller Business. Research Report to the Federation of Small Business.

European Commission, 2010. Internationalization of European SMEs. DirectorateGeneral for Enterprise and Industry.

European Commission, 2007. Simplified Tax Compliance Procedures for SMEs Final Report of the Expert Group. EC Publishing, Brussels.

Income Tax Law No. 25.784 of Argentina

Nerudová, D., 2005. Harmonizace daňových system v zemí Evropské unie, Praha: ASPI, pp. 236. Daňová řada. ISBN 80-7357-142-0.

Nerudová, D., Bohušová, H., Svoboda, P., Široký, J., 2009. Harmonizace účetních standardů pro malé a střední podniky. Praha, Wolters Kluwer.

OECD, 2010. Transfer Pricing Guidelines for Multinational Enterprises and Tax Administrations.

OECD, 2014. BEPS Action 10: Discussion Draft on Transfer Pricing aspects of cross-border commodity transactions.

Sandford, C., 1995. Tax Compliance Costs - measurement and policy. Institute for Fiscal Studies, Bath.

Van Herksen, M., 2009. Introduction. In Bakker, A., Obuoforibo, B. Transfer pricing and customs valuation. Two worlds to tax as one. IBFD. 
Solilová, V. - Nerudová, D.: Sixth Method as a Simplified Measurement for SMEs?

\section{APPENDIX}

\section{Tab. 1: Tradable commodities}

\begin{tabular}{|c|c|c|c|}
\hline Commodity & & Trading symbol & Main Exchange \\
\hline Corn & \multirow{17}{*}{$\begin{array}{l}\text { Grains, } \\
\text { food and } \\
\text { fiber }\end{array}$} & $\mathrm{C} / \mathrm{ZC}$ (Electronic) & CBOT \\
\hline Corn & & EMA & EURONEXT \\
\hline Oats & & $\mathrm{O} / \mathrm{ZO}$ (Electronic) & \multirow{3}{*}{ CBOT } \\
\hline Rough Rice & & $\mathrm{ZR}$ & \\
\hline Soybeans & & S/ZS (Electronic) & \\
\hline Rapeseed & & $\mathrm{ECO}$ & EURONEXT \\
\hline Soybean Meal & & SM/ZM (Electronic) & \multirow{3}{*}{ CBOT } \\
\hline Soybean Oil & & BO/ZL (Electronic) & \\
\hline Wheat & & W/ZW (Electronic) & \\
\hline Wheat & & EBL & EURONEXT \\
\hline Milk & & DC & $\begin{array}{l}\text { Chicago Mercantile } \\
\text { Exchange }\end{array}$ \\
\hline Cocoa & & $\mathrm{CC}$ & \multirow[t]{6}{*}{ 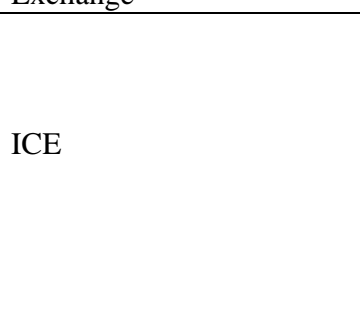 } \\
\hline Coffee $C$ & & $\mathrm{KC}$ & \\
\hline Cotton No.2 & & $\mathrm{CT}$ & \\
\hline Sugar No.11 & & SB & \\
\hline Sugar No.14 & & SE & \\
\hline $\begin{array}{l}\text { Frozen } \\
\text { Concentrated } \\
\text { Orange Juice }\end{array}$ & & FCOJ-A & \\
\hline Palm Oil & \multirow{3}{*}{ Others } & \multirow{3}{*}{ n.a. } & Bursa Malaysia \\
\hline Rubber & & & TOCOM \\
\hline Wool & & & ASX \\
\hline Lean Hogs & \multirow{3}{*}{$\begin{array}{l}\text { Livestock } \\
\text { and meat }\end{array}$} & $\mathrm{LH}$ & \multirow{3}{*}{$\begin{array}{l}\text { Chicago } \\
\text { Exchange }\end{array}$} \\
\hline Live Cattle & & LC & \\
\hline Feeder Cattle & & FC & \\
\hline WTI Crude Oil & \multirow{9}{*}{ Energy } & CL (NYMEX), WTI (ICE) & NYMEX, ICE \\
\hline Brent Crude & & B & ICE \\
\hline Ethanol & & $\begin{array}{l}\text { AC (Open Auction) ZE } \\
\text { (Electronic) }\end{array}$ & CBOT \\
\hline Natural gas & & NG & NYMEX \\
\hline Heating Oil & & $\mathrm{HO}$ & NYMEX \\
\hline $\begin{array}{l}\text { Gulf Coast } \\
\text { Gasoline }\end{array}$ & & LR & NYMEX \\
\hline $\begin{array}{l}\text { RBOB Gasoline } \\
\text { (reformulated } \\
\text { gasoline } \\
\text { blendstock for } \\
\text { oxygen blending) }\end{array}$ & & $\mathrm{RB}$ & NYMEX \\
\hline Propane & & PN & NYMEX \\
\hline $\begin{array}{l}\text { Purified } \\
\text { Terephthalic } \\
\text { Acid (PTA) }\end{array}$ & & TA & $\mathrm{ZCE}$ \\
\hline
\end{tabular}


European Financial and Accounting Journal, 2015, vol.10, no. 3, pp. 45-61.

\begin{tabular}{|c|c|c|c|}
\hline Commodity & & Trading symbol & Main Exchange \\
\hline $\begin{array}{l}\text { Copper } \\
\text { Lead } \\
\text { Zinc } \\
\text { Tin } \\
\text { Aluminium } \\
\text { Aluminium alloy } \\
\text { Nickel } \\
\text { Cobalt } \\
\text { Molybdenum } \\
\end{array}$ & \multirow[t]{2}{*}{$\begin{array}{l}\text { Metals - } \\
\text { industrial }\end{array}$} & \multirow[t]{2}{*}{ n.a } & $\begin{array}{l}\text { New York, } \\
\text { London Metal Exchange }\end{array}$ \\
\hline Recycled steel & & & Rotterdam \\
\hline $\begin{array}{l}\text { Gold } \\
\text { Platinum } \\
\text { Palladium } \\
\text { Silver }\end{array}$ & $\begin{array}{l}\text { Metals - } \\
\text { precious }\end{array}$ & n.a. & COMEX \\
\hline
\end{tabular}

